\title{
ANALYTICAL STUDY OF EXPORT MARKET STRATEGIES AND BARRIERS PERCEPTION BY INDIAN COTTON MANUFACTURING CLOTHES IN CONTEXT OF COVID-19
}

\author{
Meenakshi Singh', Shridhar Rajpathak ${ }^{2}$, Reema Sathe ${ }^{3}$ \\ ${ }^{1}$ Senior Assistant Professor, Sri Balaji University (SBU), Pune, India \\ ${ }^{2}$ Associate Professor, Sri Balaji University (SBU), Pune, India and Director Garware \\ Technical Fibers Ltd., India \\ ${ }^{3}$ Founder - Happy Roots, Consultant - Agri Supply Chains, Gender Equality in \\ Agriculture Presidential Award Winner '16- Rural Development, India
}

\begin{abstract}
The COVID-19 problem has affected India's textile industry severely. The industry must be given adequate attention in academic and policy circles because of its socioeconomic importance for the Indian economy. This paper explores various aspects of export market strategies and barriers perception by Indian cotton cloth manufacturers during the COVID-19 pandemic. The researchers examined different information from an additional reliable secondary source to provide a comprehensive study on export market strategies and barriers perception by Indian cotton manufacturing. They compiled all information related to the marketing strategies of Indian cotton manufacture. This study provides a brief overview of market strategies and barriers perception of Indian cotton and textile industries during the COVID-19 pandemic.
\end{abstract}

Key Words: Export, Market Strategies, Barriers Perception, Cotton Manufacturing, COVID-19

Cite this Article: Meenakshi Singh, Shridhar Rajpathak and Reema Sathe, Analytical Study of Export Market Strategies and Barriers Perception by Indian Cotton Manufacturing Clothes in Context of COVID-19, International Journal of Management, 11(12), 2020, pp 3491-3495.

https://iaeme.com/Home/issue/IJM?Volume=11\&Issue=12

\section{INTRODUCTION}

The COVID-19 problem has affected India's textile industry severely. Indian textile and cotton industry must be given higher importance because of its socio-economic significance for the Indian economy, and it is the second most significant industry after agriculture. An unprecedented calamity has endangered the worldwide socio-economic existence of humanity 
in the shape of the COVID-19 flu pandemic. Given the significance of COVID-19 about the country's social and economic spheres, this essay examines its influence on the globalised Indian textiles sector. The issue is discovered to have a wide range of consequences for this important business. Whether seen through the lens of consumer demand or production networks, the disaster has impacted various industrial operations. Given the breadth and depth of these impacts, it is critical for all stakeholders, including government, industry, and public, to devise creative and beneficial solutions to mitigate the detrimental effects of the crisis on this essential industry. Failure to do so may jeopardise tens of thousands of employment and stifle economic development. While the exact impact and aggressive methods will likely change as the situation progresses, the research brings together several parts of COVID-19's consequences. The study highlights the importance of thinking "out of the box" to address this unique issue. Relaxing tax compliance deadlines and standards, particularly for the lowest economic strata, might be one of the possible remedies to the crisis so that consumer demand conditions do not worsen rapidly. Also, a more comprehensive financial package has been launched to mitigate the adverse effects of the pandemic on the textile sector, taking into account labour and export-intensive industries like textiles. Another important step may be a concession to exporters under the reduction of Duties or Taxes on the Export Products system, allowing them to be compensated for duties and taxes previously unpaid.

As with a vast raw material base and manufacturing capabilities across the value chain, India's textile business is one of the worlds largest. This industry adds to industrial output (7 per cent), GDP ( 2 per cent), export earnings ( 15 per cent), and employment sources ( 45 million people). It continues to sell domestically and globally thanks to its ties to Indian agriculture, culture, and tradition. However, these industries have several export obstacles, which might be reduced to enhance and encourage exports. International business plays a significant part in improving countries' social and economic performance across the world during this time of globalisation. For India, the export relationship between diverse nations has always been critical. There are just a few hurdles that prohibit new businesses from entering a market. Companies who want to export should be aware of the barriers that hinder them from entering foreign markets. A few hidden impediments, such as culture and social power, can impact export, impact riders and stifle access to international markets. Non-tariff barriers must also be considered because they have an impact on international trade. These obstacles have a greater impact on the poor, more significant on industrialised countries. This study aimed to learn about exporters' perceptions of barriers when exporting from India to different nations.

\section{OBJECTIVES OF THE STUDY}

This paper explores various aspects of export market strategies and barriers perception by Indian cotton cloth manufacturers during the COVID-19 pandemic.

\section{RESEARCH METHODOLOGY}

The researchers explored different information from an additional reliable secondary source to provide a comprehensive study on export market strategies and barriers perception by Indian cotton manufacturing. They compiled all information related to the marketing strategies of Indian cotton manufacture. The research is based on limited published and unpublished data from limited reliable source and database.

\section{LITERATURE REVIEW}

Dhiman \& Sharma (2017) stated due to innovations such as E-commerce, better networking, and other aspects of globalisation, even smaller businesses are increasingly thinking worldwide 
and expanding internationally. However, in certain nations, specific industries continue to face difficulties that technological improvements have not addressed. They examined these intangible variables in the context of the Indian market and from the perspective of Indian small businesses and their export to other countries. They also discussed the benefits and drawbacks of growth, as well as the natural barriers to it.

Raut et al. (2019) explained COVID-19 had worsened export problems in four essential business functions: human resources, manufacturing, transportation and supply chain, and finance. The epidemic has wreaked havoc on labour-intensive manufacturing facilities while being primarily a health problem. As subcategories of the fashion sector, Leather and cotton textiles sectors have been hit hard by a drop in demand. The pandemic has highlighted institutional flaws by exposing the global industry's fragility, which requires resolution, reimagination, and transformation to be robust. They provide many recommendations for interdependent systems to attain resilience, allowing them to foresee, absorb, recover from, and adapt to the aftermath of disruptive shocks that may occur in the future - since crises do not happen "if," but "when."

Peters \& Simaens (2020) examined and stated that the textile and apparel (T\&A) industry significantly impacts the socio-economic and environmental aspects of sustainability. They used a multi-criteria decision-making technique to determine the interrelationships between the significant hurdles to the long-term growth of T\&A supply chains and to rank the barriers. Their investigation's findings indicated that the topmost important issues include a lack of effective government policies, inadequate infrastructure, a lack of a reasonable degree of integration, low foreign investment, and demonetisation.

Verma (2002) outlined the shifting face of international commerce, which is expected to influence the global textile and apparel trade substantially. They identified areas in which government policy action is required. While there is little question about the great potential of the Indian industry, particularly the garment sector, they conclude that specific legislative reforms are urgently needed to harness this latent capability. Furthermore, given the evolving nature of the global trade environment, market access looks to be an increasingly essential component of converting competitiveness into export performance.

\section{GLOBAL TRADE IN TEXTILE AND CLOTHING}

During the COVID period, textile exporters from developed and developing countries swapped shares. The percentage of developed nations fell by nearly as much $(19.2 \%)$ as the share of developing countries increased (18.8 per cent). There have been new entries as well as some previous competitors who have been eliminated. The majority, if not all, of these new immigrants are from developing nations since the percentage of industrial countries has decreased. In contrast, the share of developing countries has grown throughout this period. Governments increasing their proportion of apparel exports are those whose industries are integrated into one or more advanced countries through policy-induced advantageous arrangements. As a result, clothing has seen far greater globalisation than textiles.

\subsection{Indian Textiles and Clothing Sector Competitiveness Factors}

According to the evidence reviewed above, the 1991 reforms did an excellent job of increasing exports. Therefore, India must concentrate on improving its export share in the global market. India benefits significantly from its proximity to Bangladesh, Sri Lanka, Nepal, and Pakistan, both physically and culturally. As a result, commerce between these nations can be increased. The study indicates that labour costs affected Asian developing nations' textile and apparel export performance in distinct ways. Higher labour expenses are often associated with worse export performance. The factors such as GDP, actual exchange rates, GDP per capita, and the 
importing population rate significantly influence. The Indian Rupee's depreciation would promote textile exports because purchasers would benefit from cheaper textile items. The study also shows that non-tariff obstacles in developing nations resulted in a drop in demand for Indian exporters during 1996-97. Supply-side issues (such as delays in procedures, insufficient infrastructure) are crucial in sustaining a sustained export increase.

\section{SUPPLY CHAIN MANAGEMENT}

The supply chains, which are supplied from the supplier to the wholesaler, retailer and client, comprise the administration of items, information, and money. Supply chain management involves the management and integration of such movements both inside and between companies. It is claimed that the ultimate goal of every efficient supply chain management system is to access things when necessary.

\subsection{Location Decisions}

These decisions are essential to a firm because they define the core strategy for entering consumer markets and substantially impact income, cost, and level of service. To make these decisions, and optimisation approach should be applied to account for manufacturing cost, taxes, duty rebate, customs, local content, transportation costs, output restrictions, etc. Therefore, while site selection is mainly strategic, it is operational in export choices.

\subsection{Inventory Decisions}

These are the strategies for managing the inventory of textiles. Stocks such as raw materials, semi produced goods and finished things occur at all stages of the supply chain. They might also move from one region to another. Their primary role is to tackle any predictability in the supply chain as a buffer. During supply chain operations, efficient inventory management is crucial since inventory storage expenses range between 20 per cent to 40 per cent of their worth. Moreover, since it is an export choice, it is strategic.

\subsection{Transportation Decisions}

These decisions are more strategic when it comes to mode selection. These are indiscriminately linked to inventory decisions. The best mode is often decided by balancing the direct cost of using that mode of transport with the indirect inventory costs of that mode. Whilst transport by sea or rail is less costly; many inventories must be maintained to offset the inherent risk. The quality of customer service and the location of the company are therefore significant considerations in such choices. Because transportation accounts for more than $30 \%$ of logistics expenses, it makes financial sense to run a lean operation. The number of shipments (consolidated bulk exports vs Lot-for-Lot shipments) and the route and timing of equipment is critical to the firm's export strategy's success.

\section{GOVERNMENT FRAMEWORK AND POLICY}

Despite the many years of liberalisation and globalisation of the indigenous textiles and garment industry, 20 control orders/notifications are in place-some of the policies affect Indian textiles and apparel industries' worldwide competitiveness.

\section{CONCLUSION}

India has long been known as a manufacturing powerhouse. It is well-known for its textile industry's tradition and skillsets. With a difficult market and economic environment, the COVID-19 phase has influenced a dynamic shift over the market. The players are encountering 
difficulties in maintaining and projecting themselves as a potential hub. The study's goal is to determine the environment in which the different barriers and factors in the growth of garment production and export in the global arena interact. Indian manufacturers are influenced by several elements when it comes to foreign trading. By analysing and categorising the dependency power and the driving power of such obstacles, the article hopes to provide a new perspective on the COVID's influence on the Indian cotton and textile industries.

\section{REFERENCES}

[1] Dhiman, R., \& Sharma, M. (2017). Export competitiveness of Indian textile industry: Revealed comparative advantage analysis.

[2] Peters, J., \& Simaens, A. (2020). Integrating sustainability into corporate strategy: A case study of the textile and clothing industry. Sustainability, 12(15), 6125. Available from: https://doi.org/10.3390/su12156125

[3] Raut, R., Gardas, B. B., \& Narkhede, B. (2019). Ranking the barriers of sustainable textile and apparel supply chains: an interpretive structural modelling methodology. Benchmarking: An International Journal. Available from: https://doi.org/10.1108/BIJ-12-2017-0340

[4] Sharma, M., \& Dhiman, R. (2016). Determinants are affecting Indian textile exports: a review. Biz Bytes J Manag Technol, 6, 193-199.

[5] Verma, S. (2002). Export competitiveness of Indian textile and garment industry. Indian Council for Research on International Economic Relations, Working Paper, 94. 